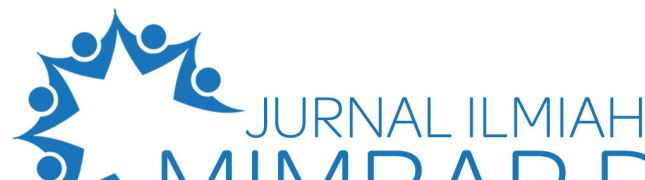 कMIMBAR DEMOKRASI

Vol. 21 No. 1 October 2021 | Hal. 8 - 18

\section{Perilaku pemilih pada pemilihan umum kepala daerah Kota Tangerang Selatan dalam masa pandemi covid-19}

\author{
Abd. Chaidir Marasabessy a,1*, Nurdiyanaa, ${ }^{a, 2}$, Setiawatia,3 Ichwani Siti Utamia, 4 \\ Prodi PPKn, Fakultas Keguruan dan Ilmu Pendidikan, Universitas Pamulang, Indonesia \\ 1dosen02633@unpam.ac.id; ${ }^{2}$ dosen02080@unpam.ac.id; ${ }^{3}$ dosen02084@unpam.ac.id, ${ }^{4}$ dosen00655@unpam.ac.id \\ *Korespondensi penulis
}

\begin{tabular}{l}
\hline Informasi artikel \\
\hline Diterima: \\
30-07-2021 \\
Disetujui: \\
21-09-2021
\end{tabular}

Kata kunci:

Perilaku pemilih

Pemilu

Covid-19

\section{Received: \\ 30-07-2021 \\ Accepted: \\ 21-09-2021 \\ Keywords: \\ Voter behavior, \\ elections, the Covid-19 \\ pandemic}

\begin{abstract}
ABSTRAK
Penelitian ini bertujuan untuk menganalisis kondisi riil perilaku pemilih pada pemilihan umum kepala daerah Kota Tangerang Selatan dalam masa pandemi Covid-19, dan mengidentifikasi faktor-faktor yang mempengaruhi perilaku pemilih pada Pemilihan Umum Kepala Daerah Kota Tangerang Selatan dalam masa pandemi Covid-19. Penelitian ini adalah penelitian kualitatif deskriptif. Subjek penelitian adalah warga masyarakat di wilayah Benda Baru Kecamatan Pamulang. Pengumpulan data dilakukan dengan wawancara, observasi, dan dokumentasi. Hasil penelitian disimpulkan bahwa; 1) Partisipasi pemilih pada ajang pemilihan kepala daerah tahun 2020 di wilayah Benda Baru Pamulang sebanyak 18.982 jiwa atau mencapai 61 persen dan yang tidak menggunakan hak pilih sebanyak 12.132 atau mencapai 39 persen, dari total jumlah jiwa pilih sebanyak 31.114 jiwa pilih. Sementara perilaku pemilih dalam menentukan hak politiknya masih didominasi oleh sosok figur dan politik uang (money politics). 2) Kekhawatiran warga akan keselamatan jiwa akibat penularan wabah covid-19 yang menjadi faktor utama menurunnya partisipasi masyarakat dalam menggunakan hak pilih pada pemilihan kepada daerah di wilayah Benda Baru Pamulang Kota Tangerang Selatan.

ABSTRACT

Voter Behavior in Regional Head Elections South Tangerang City During the Covid-19 Pandemic. This study aims to analyze the real condition of voter behavior in the South Tangerang City Regional Head Election during the Covid-19 pandemic, and identify factors that influence voter behavior in the South Tangerang City Regional Head Election during the Covid-19 pandemic. This research is a descriptive qualitative research. The research subjects were community members in the Benda Baru area, Pamulang District. Data collection is done by interview, observation, and documentation. The results of the study concluded that; 1) Voter participation in the 2020 regional head election in the Benda Baru Pamulang area was 18,982 people or reached 61 percent and 12,132 people did not exercise their right to vote, or 39 percent, of the total number of people voting as many as 31,114 people. Meanwbile, the behavior of voters in determining their political rights is still dominated by figures and money politics. 2) Citizens' concerns about life safety due to the transmission of the covid-19 outbreak which is the main factor in the decline in public participation in exercising their right to vote in elections to regions in the Benda Baru Pamulang area, South Tangerang City.
\end{abstract}

Copyright (C) 2021 (Abd. Chaidir Marasabessy, Nurdiyana, Setiawati, Ichwani Siti Utami). All Rights Reserved

How to Cite: Marasabessy, A.C., Nurdiyana, Setiawati, \& Utami, I.S. (2021). Perilaku pemilih pada pemilihan umum kepala daerah Kota Tangerang Selatan dalam masa pandemi covid-19. Jurnal Ilmiah Mimbar Demokrasi, 21(1), 8-18. DOI: http://doi.org/10.21009/jimd.v21i1.22147

This work is licensed under a Creative Commons Attribution-ShareAlike 4.0 International License. Allows readers to read, download, copy, distribute, print, search, or link to the full texts of its articles and allow readers to use them for any other lanful purpose. The author (s) holds the copyright.

\section{Pendahuluan}

Pemilihan umum atau pemilihan kepala daerah dapat dikatakan menjadi suatu jembatan dalam menentukan bagaimana pemerintahan dapat dibentuk secara demokratis. Oleh karenanya rakyat menjadi penentu dalam memilih 


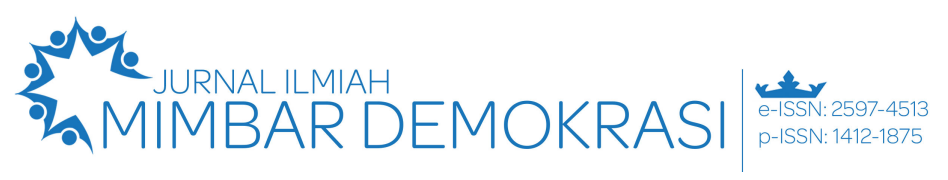

Vol. 21 No. 1 October 2021 | Hal. 8 - 18

pemimpin yang kemudian akan mengarahkan perjalanan suatu bangsa. Dalam sistem politik, pemilihan umum bermakna sebagai saran penghubung antara infrastruktur politik dengan suprastruktur politik, sehingga akan terciptanya pemerintahan dari, oleh, dan untuk rakyat. Oleh karenanya, dalam proses demokratisasi, rakyat sebagai pemegang kedaulatan tertinggi dalam negara yang kemudian termanifestasikan melalui pemilihan umum yang dilaksanakan setiap lima tahun sekali. Keikutsertaan warga negara dalam pemilihan umum merupakan hak politik setiap warga negara yang dijamin oleh Undang-Undang. Studi tentang pemilihan umum menghasilkan beberapa tipe perilaku pemilih. Keikutsertaan warga negara dalam pemilihan umum serangkaian kegiatan membuat keputusan yaitu apakah memilih atau tidak memilih dalam pemilihan umum. Jika memutuskan untuk memilih, apakah yang dipilih partai politik atau figur (kandidat). Hal ini, menunjukkan bahwa tindakan politik warga negara, memang selalu bergerak dari tidak terlibat sama sekali, terlibat secara terbatas hingga terlibat secara penuh dalam kegiatan politik. Mereka yang tidak terlibat sama sekali dalam kegiatan politik dalam arti sikap masa bodoh atau apatis dapat disebabkan beberapa hal, di antaranya; sikap acuh tak acuh, tidak tertarik pada politik, kurang mengerti masalah politik, tidak yakin bahwa usaha dalam memengaruhi kebijakan publik akan berhasil dan lain sebagainya.

Perilaku politik dapat katakan sebagai proses pembuatan dan pelaksanaan proses politik. Hal ini dijelaskan Ramlan Surbakti, bahwa kegiatan ini meliputi antara lembaga-lembaga pemerintah, kelompok-kelompok, dan individuindividu di dalam masyarakat dalam rangka pembuatan, pelaksanaan, dan penegakan keputusan politik. Kegiatan yang dilakukan itu pada dasarnya dibagi ke dalam 2 (dua) bagian, yaitu fungsi-fungsi politik yang dipegang oleh masyarakat, namun fungsi pemerintahan, maupun fungsi politik, biasanya dilaksanakan oleh struktur tersendiri, yaitu suprastruktur politik bagi fungsi-fungsi politik pemerintah dan infrastruktur politik bagi fungsi-fungsi politik Masyarakat. Oleh karena itu, partisipasi politik sangat memengaruhi jumlah suara dari setiap calon kepala daerah yang mencalonkan diri. Semakin tinggi tingkat partisipasi pemilih, maka tingkat kerberhasilan Pilkada semakin tinggi (Surbakti, 2010; Mopeng, 2016).

Jadi, partisipasi politik sangat memengaruhi jumlah suara dari setiap calon kepala daerah yang ada. Hal inilah yang merupakan penyebab berhasil atau tidaknya pemilihan umum di suatu daerah. Semakin tinggi tingkat partisipasi warga negara dalam pemilihan umum, maka semakin tinggi pula kerberhasilannya, dan pada gilirannya demokrasi kita akan menjadi baik dan berkualitas.

Sebagaimana dijelaskan Miriam Budiardjo, bahwa partisipasi politik sebagai kegiatan seseorang atau sekelompok orang untuk ikut secara aktif dalam kehidupan politik yaitu dengan cara memilih pemimpin negara secara langsung atau tidak langsung, memengaruhi kebijakan pemerintah. Kegiatan ini mencakup tindakan seperti memberikan suara dalam pemilihan umum, menghadiri rapat umum, menjadi anggota partai atau kelompok kepentingan, mengadakan hubungan dengan pejabat pemerintah atau anggota parlemen (Miriam Budiardjo, 2000).

Pemilihan Kepala Daerah di 270 wilayah di Indonesia tahun 2020 yang dilakukan secara serentak tahun 2020 berbeda dari sebelumnya. Pilkada serentak yang digelar pada tanggal 9 Desember 2020 dalam situasi pandemi Covid-19 belum mereda. Dengan situasi yang demikian, maka Komisi Pemilihan Umum (KPU) melakukan pembatasan di seluruh tahapan guna mencegah potensi penyebaran virus Covid-19 tersebut. Dalam peraturan KPU (PKPU) Nomor 13 Tahun 2020 tentang Perubahan Kedua atas PKPU Nomor 6 Tahun 2020 tentang Pelaksanaan Pilkada serentak lanjutan dalam kondisi bencana non-alam Covid-19 mengatur secara spesifik terkait dengan larangan yang dilakukan dalam pelaksanaannya. Namun seiring berjalannya masa kampanye pemilihan Kepala Daerah yang dimulai bulan September 2020, para pasangan calon kepala daerah mencari siasat untuk mengumpulkan dukungan masyarakat dalam situasi pandemi Covid-19. Bila dicermati kondisi ini sangat memprihatinkan, karena baik kandidat maupun simpatisan terkesan mengabaikan protokol kesehatan, padahal penularan wabah Covid-19 masih cukup tinggi. Berdasarkan hasil observasi awal yang dilakukan di beberapa titik di wilayah Benda Baru Kecamatan Pamulang, terungkap bahwa warga masyarakat yang mengikuti silahturahmi (kampanye) terkesan abai terhadap protokol kesehatan, bahkan kandidat maupun tim sukses tidak memberikan arahan pada warga untuk menjaga jarak, padahal situasi pandemi Covid-19 masih cukup tinggi penularannya. Hal ini menunjukkan bahwa warga abai terhadap 
keselamatan jiwa mereka pada situasi genting seperti ini. Di sisi lain, kandidat maupun tim suksesnya terkesan sengaja membiarkan kerumunan warga bahkan lupa akan anjuran pemerintah terkait dengan penerapan protokol kesehatan. Oleh karena itu, patut diduga ada terjadi praktik politik uang dalam kampanye tersebut. Dugaan ini juga didasarkan interview terhadap 2 (dua) warga setempat bahwa memang ada pemberian sejumlah uang dengan jumlah yang variatif antara lima puluh ribu rupiah hingga seratus ribu rupiah dalam kegiatan silahturahmi tersebut.

Berangkat dari paparan tersebut, peneliti tertarik untuk meneliti perilaku pemilih pada pilkada dalam masa pandemi Covid-19. Fokus permasalahan dalam penelitan ini adalah, bagaimanakah rasionalitas perilaku pemilih pada pemilihan umum kepala daerah Kota Tangerang Selatan dalam masa pandemi Covid-19 dan faktor apa yang memengaruhi perilaku pemilih pada pemilihan umum kepala daerah Kota Tangerang Selatan dalam masa pandemi Covid-19? Peneltian ini bertujuan; untuk menganalisis kondisi riil perilaku pemilih pada pemilihan umum kepala daerah Kota Tangerang Selatan dalam masa pandemi Covid-19 dan mengidentifikasi faktorfaktor yang memengaruhi perilaku pemilih pada Pemilihan Umum Kepala Daerah Kota Tangerang Selatan dalam masa pandemi Covid19.

Secara teoritis manfaat yang diharapkan dari penelitian ini adalah dapat memperkaya khazanah kajian ilmu politik dalam upaya pengembangan ilmu pengetahuan, menambah pengalaman dalam meningkatkan pengetahuan, kemampuan dalam melakukan penelitian sebagai peneliti, dan secara praktis sebagai bahan masukan atau informasi bagi penelitian lebih lanjut yang tertarik mengkaji fenomena yang serupa.

\section{Metode}

Lokasi penelitian di wilayah Kelurahan Benda Baru Kecamatan Pamulang Kota Tangerang Selatan. Pertimbangan peneliti memilih lokasi tersebut, karena; 1) penyebaran wabah pandemi covid-19 masih cukup tinggi, 2) biaya dan alokasi waktu, serta akses ke lokasi penelitian mudah dijangkau. Jenis penelitian yang digunakan adalah kualitatif deskriptif. Menurut Moleong (2007) penelitian deskriptif kualitatif adalah penelitian yang bermaksud untuk memahami fenomena tentang apa yang dialami oleh subjek penelitian, misalnya perilaku, persepsi, motivasi, tindakan dan lain-lain, secara holistik dan dengan cara alamiah dan memanfaatkan berbagai metode alamiah. Sumber data yang digunakan, meliputi; data primer dan sekunder. Data primer diperoleh dari hasil observasi dan wawancara yang mendalam, sedangkan data sekunder diambil dari artikel, jurnal, dan sumber lainnya yang relevan dengan penelitian dimaksud. Subjek penelitian adalah warga masyarakat di wilayah Benda Baru Kecamatan Pamulang. Instrumen pengumpulan data dilakukan dengan menggunakan wawancara, observasi dan dokumentasi. Teknik analisis data yang digunakan dalam penelitian ini adalah teknik analisis data yang dilakukan secara interaktif, dengan merujuk pada model Miles dan Huberman (Sugiyono, 2016) meliputi; 1) aktivitas pengumpulan data, 2) reduksi data, dan 3) penyajian data, dan penarikan kesimpulan/verifikasi.

\section{Hasil dan Pembahasan \\ Perilaku Pemilih dalam Masa Pandemi Covid-19}

Pemilihan Kepala Daerah serentak tahun 2020 yang digelar di 270 daerah relatif sukses dilaksanakan, meski demikian, pemilihan umum kepala daerah berlangsung di tengah wabah pandemi Covid-19, tak terkecuali warga yang berdomisili di Kota Tangerang Selatan. Di wilayah Kelurahan Benda Baru Kecamatan Pamulang, Pemungutan suara berlangsung di 97 Tempat Pemungutan Suara (TPS) dengan menjalankan protokol kesehatan sesuai dengan Peraturan KPU (PKPU) Nomor 13 Tahun 2020 tentang Perubahan Kedua atas PKPU Nomor 6 Tahun 2020 tentang Pelaksanaan Pemilihan Kepala Daerah Serentak Lanjutan dalam Kondisi Bencana Non-alam Covid-19. Berdasarkan hasil pengamatan yang dilakukan, para Petugas PPS menggunakan alat pelindung diri seperti, masker, sarung tangan, sementara pemilih memakai masker maupun penutup wajah. Selain itu, di setiap Tempat Pemungutan Suara (TPS) juga disediakan handsanitizer maupun tempat mencuci tangan. Pemungutan suara juga berlangsung di sejumlah tempat isolasi mandiri di rumah dengan petugas yang mendatangi rumah pemilih. Meski demikian, sejumlah warga masyarakat mengaku tidak mau datang ke tempat pemungutan suara (TPS) untuk menggunakan haknya karena mereka masih khawatir dengan potensi penularan wabah virus Covid-19. Oleh karena itu, pilkada serentak tahun 2020 bakal tercatat dalam sejarah sebagai 


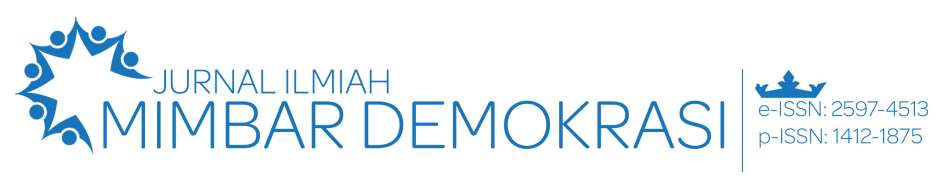

Vol. 21 No. 1 October 2021 | Hal. 8 - 18

peristiwa politik besar yang digelar di tengah wabah pandemi Covid-19.

Selanjutnya berdasarkan Keputusan Komisi Pemilihan Umum Nomor: 83/PL.02.1$\mathrm{Pu} / 01 / 3674 / \mathrm{KPU}$ Kot/XI/2020 tentang daftar pemilih tetap (DPT) pemilihan Walikota dan Wakil Walikota Tangerang Selatan tahun 2020, di wilayah Kelurahan Benda Baru Kecamatan Pamulang, yang mempunyai hak pilih pada pemilihan Kepala Daerah sebanyak 31.114 jiwa pilih, terdiri dari pemilih laki-laki sebanyak 15.373 dan pemilih perempuan sebanyak 15.741, yang tersebar pada 97 Tempat Pemungutan Suara (KPU Tangsel, 2020).

Berikut daftar pemilih tetap (DPT) wilayah Benda Baru Kecamatan Pamulang dalam pemilihan umum kepala daerah tahun 2020, dapat ditunjukkan pada tabel berikut (KPU Tangsel, 2020):

Tabel 1. Jumlah DPT

\begin{tabular}{lll}
\hline No & \multicolumn{2}{l}{ Jumlah Jiwa Pilih } \\
\cline { 2 - 3 } & Laki- laki & Perempuan \\
1 & 15.373 & 15.741 \\
\hline
\end{tabular}

Dari hasil temuan di lapangan pelaksanaan pemilihan Kepala Daerah Kota Tangerang Selatan, di wilayah Kelurahan Benda Baru Kecamatan Pamulang dalam masa pandemi Covid-19, memperlihatkan bahwa partisipasi warga dalam menggunakan hak pilih dalam pemilihan Kepala Daerah tahun 2020 masih rendah. Berdasarkan data pemilih tetap (DPT) di Kelurahan Benda Baru Kecamatan Pamulang, tahun 2020 berjumlah 31.114 jiwa. Warga yang menggunakan hak pilih pada pemilihan kepala daerah berjumlah 18.982 jiwa, sedangkan yang tidak menggunakan hak pilih (golput) berjumlah 12.132 jiwa (KPU Tangsel, 2020).

Berdasarkan hasil perhitungan perolehan suara dari Komisi Pemilihan Umum (KPU) Kota Tangerang Selatan pada pemilihan umum kepala daerah tahun 2020 di Wilayah Benda Baru Kecamatan Pamulang, menunjukkan bahwa partisipasi warga masyarakat dalam pemilihan Kepala Daerah Kota Tangerang Selatan tahun 2020 masa pandemi Covid-19 masih rendah, walaupun secara persentase terdapat peningkatan, tetapi hanya mencapai 2,2 persen. Dari hasil rekapitulasi perolehan suara pada pemilihan umum kepala daerah Kota Tangerang Selatan pada wilayah Kelurahan Benda Baru Kecamatan Pamulang, menunjukkan bahwa partisipasi pemilih dalam ajang pemilihan kepala daerah sebanyak 18.982 jiwa atau mencapai 61 persen dan warga masyarakat yang tidak menggunakan hak pilih (golput) pada Pilkada sebanyak 12.132 atau mencapai 39 persen, dari total jumlah jiwa pilih sebanyak 31.114 jiwa pilih. Apabila dibandingkan dengan pemilihan umum kepala daerah periode sebelumnya di ajang pemilihan umum kepala daerah tahun 2015 partisipasi warga masyarakat Benda Baru Kecamatan Pamulang hanya mencapai 58,80 persen, di mana dari jumlah jiwa pilih sebanyak 28.629 jiwa, dan yang menggunakan hak pilih sebanyak 16.833 jiwa sedangkan yang tidak menggunakan hak pilih (golput) sebanyak 11.796 jiwa. (KPU Tangsel, 2015).

Dengan demikian, maka dapat dikatakan bahwa tingkat partisipasi warga masyarakat dalam pemilihan kepala daerah kota Tangerang Selatan tahun 2020 masih rendah. Hal ini disebabkan warga masih merasa khawatir dan merasa ketakutan dengan penularan Covid-19 yang sampai saat ini masih cukup tinggi. Hal ini juga didasarkan pada hasil interview peneliti dengan beberapa petugas PPS yang ada di lapangan.

Kekhawatiran warga untuk tidak menggunakan hak pilih pada pemilihan kepala daerah tahun 2020 di wilayah Kelurahan Benda Baru Kecamatan Pamulang Kota Tangerang Selatan dalam situasi pandemi Covid-19 ini cukup beralasan. Pelaksanaan pemilihan kepala daerah yang dilaksanakan secara serentak pada tanggal 9 Desember 2020 dikhawatirkan dapat menimbulkan klaster baru, mengingat bahwa wabah pandemi penularan virus Covid-19 belum juga berakhir. Di mana setiap tempat pengumutan suara (TPS) akan terjadi kerumunan warga yang akan menggunakan hak politiknya pada pemilihan kepala daerah.

Kondisi ini jauh sebelumnya telah diprediksi. Hasil survei Lembaga Survei Indonesia (LSI) tahun 2020, yang dirilis oleh CNN Indonesia, menunjukkan sebanyak 46 persen warga tidak mendatangi tempat pemungutan suara (TPS) pada pilkada Serentak tahun 2020 yang dilaksanakan dalam situasi genting akibat penularan Covid-19, sehingga potensi penurunan angka partisipasi warga dalam Pilkada akan terjadi (CNN, 2020).

Meskipun, kelompok pakar Covid-19 Gugus Tugas Dewi Nur Aisyah, melalui konferensi pers di BNPB menyimpulkan hasil pemantauan pemilihan kepala daerah serentak 
(Pilkada) 2020 di 34.014 titik di 229 Kabupaten/Kota menunjukkan tingkat kepatuhan pemilih terhadap penerapan protokol kesehatan cukup tinggi, berada pada kisaran 96,59 persen serta kerentanan terhadap jarak fisik berada pada kisaran 91,46 persen. Lebih lanjut dikatakan, tingkat kepatuhan protokol kesehatan tertinggi di Provinsi Sulawesi Tenggara, sedangkan penerapan protokol kesehatan di Provinsi Papua relatif kecil (CNN, 2020).

Hasil penelitian menunjukkan, masyarakat pemilih rasional di wilayah Benda Baru Pamulang justru lebih mempertimbangkan aspek keamanan pada Tempat Pemungutan Suara (TPS). Pertimbangan ini juga merupakan hal mendasar. Atas dasar itu, penulis menyimpulkan bahwa rendahnya partisipasi politik pada Pilkada 2020 diakibatkan warga masih khawatir dengan penularan wabah Covid-19 cukup tinggi, sehingga warga lebih memilih tinggal di rumah demi menjaga kesehatan dan kenyamanan mereka karena kurang terjamin tingkat keamanan di tiap-tiap TPS.

Jika kita berangkat dari gagasan dasar teori pilihan rasional Coleman dalam (Ritzer \& Douglas, 2012) yang dikutip Rejeki dijelaskan bahwa tindakan perseorangan mengarah pada satu tujuan dan tujuan tersebut adalah tindakan yang ditentukan oleh nilai atau preferensi (pilihan). Coleman juga menambahkan bahwa aktor adalah dianggap sebagai individu yang memiliki tujuan, aktor juga memiliki suatu pilihan yang bernilai dasar yang digunakan aktor untuk menentukan pilihan, yaitu menggunakan pertimbangan secara mendalam berdasarkan kesadarannya, selain itu juga aktor mempunyai kekuatan sebagai upaya untuk menentukan pilihan dan tindakan yang menjadi keinginannya (Rejeki, 2016).

Menurut penulis, atas dasar pilihan yang bernilai dasar itulah yang dijadikan pijakan masyarakat rasional dalam menentukan pilihan dan tindakan politiknya. Oleh karena itu pihak penyelenggara harus bekerja ekstra ketat untuk meyakinkan masyarakat pemilih rasional serta memberikan proteksi bahwa TPS adalah tempat yang nyaman. Sehingga Pilkada di masa pandemi Covid-19 yang menurut berbagai pihak seolah-olah terkesan dipaksakan, dapat terimbangi dengan kebijakan-kebijakan pihak penyelenggara dalam memastikan proteksi keselamatan pemilih dalam menyalurkan hak konstitusionalnya. Karena pada situasi urgen seperti ini, pemilih rasional bukan saja menjatuhkan pilihannya atas bobot kualitas visi misi kandidat semata, tetapi lebih pada pertimbangan keselamatan jiwa mereka. Hal ini menjadi poin penting apabila Pilkada dilaksanakan dalam kondisi pandemi wabah Covid-19.

Meskipun demikian, ajang Pilkada Kota Tangerang Selatan tahun 2020, khususnya di wilayah Benda Baru Kecamatan Pamulang, tidak terlepas dari praktik money politics. Penulis juga menemukan bahwa secara politis, pemilih didominasi faktor imbalan dalam bentuk uang dalam menentukan pilihannya. Berdasarkan hasil interview, ditemukan sebagian pemilih masih bergantung pada imbalan uang bahkan terungkap juga ada yang diiming-iming oknum politisi akan diberikan fasililtas. Hal ini juga turut memengaruhi pilihan politik mereka. Kecenderungan warga dalam menentukan pilihan politik bukan karena partai politik atau tingkat pendidikan, kesamaan etnis/suku, tetapi kecenderungan pada imbalan uang. Karena pada setiap perhelatan Pemilu baik pemilihan Presiden, Gubernur, Bupati/Walikota, pemilih pragmatis selalu mewarnai ajang demokrasi yang dilaksanakan 5 (lima) tahun sekali. Keterlibatan seseorang dalam berbagai aktivitas politik tentunya dihubungkan dengan motivasinya. Terutama berkaitan dengan lingkungan sosialnya. Karena lingkungan sosial menjadi variabel yang akan menggerakan munculnya motivasi.

Perilaku politik dan pilihan politik adalah sebuah konstruksi sosial. Sebagai manifestasi sikap politik, pilihan politik tidak dapat dipisahkan dari budaya politik yang oleh Almond dan Verba, yang dikutip Nursal, (2004) diartikan sebagai suatu sikap orientasi yang khas warga negara terhadap sistem politik dan aneka ragam bagiannya serta sikap terhadap peranan warga negara di dalam sistem itu.

Berdasarkan hasil penelitian ditemukan juga bahwa pelaksanaan pemilihan umum kepala daerah Kota Tangerang Selatan tahun 2020 dalam situasi pandemi Covid-19, masih ada ditemukan praktik politik uang. Padahal dalam momentum pemilihan umum kepala daerah yang seharusnya dilaksanakan dengan asas jujur, adil, bebas, dan rahasia, masih saja dikotori dengan kampanye terselebung yang dilakukan oknum politisi dengan menyisipkan kegiatannya dengan cara-cara yang tidak adil, yaitu dengan cara memberikan sejumlah uang kepada warga. Hal ini menunjukkan bahwa 


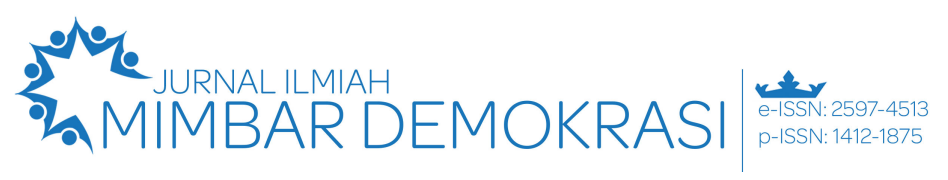

Vol. 21 No. 1 October 2021 | Hal. 8 - 18

dalam pelaksanaan Pilkada politik uang masih mewarnai pesta demokrasi ini. Maraknya politik uang (money politics) ini seolah-olah dianggap sesuatu yang biasa saja. Bahkan dianggap sebagai suatu strategi yang dapat menjaring pundi-pundi suara dari warga masyarakat setempat. Dan ironisnya lagi, masyarakat yang ditawari dengan uang dan berbagai janji-janji dari oknum politisi tertentu justru warga dengan mudah menerimanya. Mereka berdalil bahwa hal ini sebagai momentum untuk memperoleh fasilitas dari calon untuk kepentingan warga setempat. Sehingga terkadang sulit dibedakan antara bantuan dan mana yang kategori suap (jual beli suara).

Dengan demikian, dapat diasumsikan bahwa masyarakat yang memiliki pengetahuan rendah tentang politik cenderung tidak kritis menanggapi persoalan ini. Mereka cenderung berorientasi pada uang yang berjumlah tidak seberapa, jika dibandingkan dengan memikirkan pada perbaikan kondisi pemerintahan dalam jangka panjang. Sehingga praktek politik uang menjelang pemilu seakan menjadi hal yang lazim dilakukan dan warga pun berasumsi bahwa hal ini adalah sesuatu yang biasa saja.

Perilaku pemilih atau sikap politik warga masyarakat tersebut merupakan sebuah contoh kecil. Dan masih banyak perilaku pemilih masih dipengaruhi perilaku yang mudah termobilisasi dan sangat resistensi terhadap figur lain ketika ada yang mencoba mengacaukan pilihan politik mereka. Sehingga rasionalitas pemilih pada pemilihan umum terkadang hilang dengan strategi para oknumoknum politisi yang menjalankan politik uang (money politics). Hal ini juga yang mengakibatkan sedikit kesulitan untuk membedakan, mana pemilih yang rasional dengan pemilih yang tidak rasional. Karena masih banyak warga masyarakat di wilayah Kelurahan Benda Baru yang menentukan pilihan politiknya didasarkan pada suatu imbalan (uang). Sehingga kekuatan mesin politik (partai politik) dapat dikatakan tidak berperan besar dalam memperoleh simpati warga pada pemilihan umum kepala daerah. Pada sisi lain perilaku pemilih yang pragmatis masih saja ditemukan dalam setiap pelaksanaan pemilu/pilkada.

Berkaca dari fenomena tersebut, maka diasumsikan bahwa pendidikan politik di Indonesia saat ini belum menyentuh pada seluruh lapisan masyarakat. Selain itu, kurangnya kesadaran masyarakat tentang politik yang baik. Sehingga dikhawatirkan akan mengakibatkan kualitas politik menjadi buruk di masa yang akan datang. Sikap masyarakat yang membenarkan politik uang demi perbaikan fasilitas merupakan bukti bahwa budaya politik warga masyarakat masih rendah. Kemungkinan perasaan jengkel juga dari warga masyarat terhadap oknum-oknum politisi yang kerap kali melakukan tindakan koruptif. Seakan masyarakat merasa bahwa tidak ada cara lain untuk meningkatkan fasilitas setempat kecuali dengan memanfaatkan uang dari calon dalam momentum pemilu/pilkada ini.

Pelanggaran yang seringkali terjadi pada pelaksanaan pemilihan umum atau pemilihan kepala daerah, dengan adanya praktik politik uang seperti ini, justru dapat mencederai demokrasi yang dibangun dengan susah payah, bahkan politik uang (money politics) yang masih saja terjadi pada momen pilkada, seakan menjadi suatu hal yang biasa saja, sehingga mencoreng makna dari demokrasi yang sesungguhnya.

Sebagaimana dikatakan Damsar dan Indrayani (2015) yang dikutip oleh Fitriani et al (2019), bahwa berbagai pemikiran teori yang dikemukakan oleh George Caspar Homans, Peter Blau, Richard Emerson, John dan Harrold Kelly, maka dapat ditarik suatu pemahaman bahwa teori pertukaran memiliki asumsi dasar sebagai makhluk yang rasional, memperhitungkan untung rugi. Lebih lanjut dikatakan Damsar dan Indrayani (2015) bahwa teori pertukaran melihat bahwa manusia terusmenerus terlibat dalam memilih di antara perilaku-perilaku alternatif, dengan pilihan mencerminkan cost and reward (biaya dan ganjaran) yang diharapkan berhubungan dengan garis-garis perilaku alternatif tersebut, dimana dapat dikatakan bahwa suatu tindakan adalah rasional berdasarkan perhitungan untung rugi (Fitriani et al, 2019).

Dari teori pertukaran ini, kita bisa melihat bahwa fenomena politik uang yang terjadi tidak terlepas dari interaksi sosial antara individu dengan calon, keuntungan ataupun kerugian yang bisa didapatkannya dari praktek politik uang yang terjadi dalam pemilu yang akhirnya menjadi pertimbangan masyarakat dalam menentukan preferensi mereka dalam memilih calon dalam pemilu (Fitriani et al, 2019). Sehingga dengan demikian, dapat dikatakan bahwa dalam momen seperti ini, uang terkadang menjadi alat yang sangat ampuh 
dalam memengaruhi warga masyarakat guna memilih calon kepala daerah tertentu.

$$
\text { Dalam pandangan Charles Andrain }
$$

(1992) yang dikutip Damsar (2015), mengungkapkan bahwa kekuasaan dimengerti sebagai penggunaan sejumlah sumber daya (aset kemampuan) untuk memperoleh kepatuhan (tingkah laku menyesuaikan) dari orang lain. Lebih lanjut dikatakan Charles Andraian, bahwa mendapatkan kekuasaan, seseorang membutuhkan sumber daya yang bisa digunakan untuk menunjang dan membantunya dalam mendapatkan kekuasaan tersebut, bahkan dengan sumber daya yang dimiliki seseorang bisa mendapatkan kekuasaan dan mampu membuat orang lain tunduk dan patuh terhadap apa yang diinginkannya. Sebab dengan ekonomi seseorang akan mampu untuk melakukan berbagai usaha dengan sumber daya ekonomi yang dimiliki tersebut untuk mendapatkan apa yang menjadi tujuannya dalam hal ini adalah kekuasaan.

Faktor yang Memengaruhi Perilaku Pemilih pada Pilkada dalam Masa Pandemi Covid-19. Pelaksanaan pemilu/pilkada di tengah pandemi Covid-19 diprediksi akan memengaruhi jumlah warga masyarakat yang akan datang ke tempat pemungutan suara (TPS). Dari aspek rasionalitas perilaku pemilih, dipastikan bahwa warga masyarakat lebih mempertimbangkan faktor keamanan dan keselamatan di saat berada di Tempat Pemungutan Suara (TPS) dari penularan Covid19. Berdasarkan hasil temuan di lapangan, bahwa faktor-faktor yang memengaruhi perilaku pemilih dalam pemilihan umum kepala daerah Kota Tangerang Selatan tahun 2020 dalam masa pandemi Covid-19, di wilayah Kelurahan Benda Baru Kecamatan Pamulang, di antaranya faktor keamananan dan keselamatan akibat penyebaran Covid-19 yang hingga sampai saat ini belum juga berakhir. Hal ini juga menjadi pertimbangan warga tidak mau datang ke tempat pemungutan suara (TPS) untuk menggunakan hak pilih politiknya. Sebagian warga (pemilih rasional) mengungkapkan bahwa dengan adanya penerapan protokol kesehatan di setiap TPS, bukan berarti warga masyarakat telah terjamin keselamatannya dalam menyalurkan hak pilih dalam kondisi pandemi Covid-19. Oleh karena itu, warga lebih cenderung mengambil sikap dengan berdiam diri di rumah dan tidak datang ke TPS untuk menggunakan hak pilih, dengan alasan mudah tertular Covid-19.

Kekhawatiran warga untuk tidak menggunakan hak pilih dalam pemilu/pilkada dalam masa pandemi Covid-19, cukup beralasan, karena di beberapa pemberitaan di beberapa media televisi, banyak tokoh-tokoh politik maupun organisasi kemasyarakatan yang menghimbau agar pelaksanaan pemilu/pilkada di tengah pandemi Covid-19 bisa dimundurkan hingga wabah pandemi ini berakhir, karena dikhawatirkan akan menjadi klaster baru penularan virus Covid-19. Kalau dilihat dari pendekatan rasional terkait dengan bagaimana pemilih menghitung untung rugi kalau memilih. Sehingga pemilih rasional akan mencari berbagai informasi dengan sendirinya, baik melalui media televisi maupun media cetak, yang rasional ini penting karena faktor keselamatan dan kesehatan juga akan dipentingkan ketika warga memilih calon kepala daerah.

Selain itu, faktor sosok figur juga menjadi pertimbangan pemilih. Pemilih yang aktif akan melihat siapa figur yang paling cocok untuk dipilih termasuk melihat programprogram kandidat yang sesuai kebutuhan dan menguntungkan masyarakat. Bagaimana cara kandidat mengemas program-program yang dibutuhkan pemilih rasional sehingga membuat pemilih merasa penting untuk menggunakan hak pilihnya karena program-program yang ditawarkan kandidat akan membawa perubahan bagi kepentingan publik.

Dengan demikian, dapat dikatakan bahwa faktor figur juga merupakan salah satu yang menjadi pertimbangan perilaku pemilih dalam menentukan pilihan politiknya. Beberapa program yang biasanya diusung figur (calon) akan menjadi pertimbangan bagi warga masyarakat dalam menjatuhkan pilihan pada saat pemilu/pilkada. Sebagaimana ditegaskan Nursal (2004) bahwa kualitas figur seringkali menentukan keputusan pilihan dibandingkan isu karena orang lebih mudah terinformasi oleh fakta mengenai manusia dibandingkan fakta tentang isu.

Selain faktor figur yang merupakan salah satu pertimbangan bagi masyarakat dalam menentukan pilihan politiknya, ternyata preferensi lain yang tak kalah pentingnya adalah perilaku pemilih skeptis yang masih saja mewarnai hajatan pemilihan umum kepala daerah. Mereka mengharapkan semacam imbalan dari calon kepala daerah sebelum 


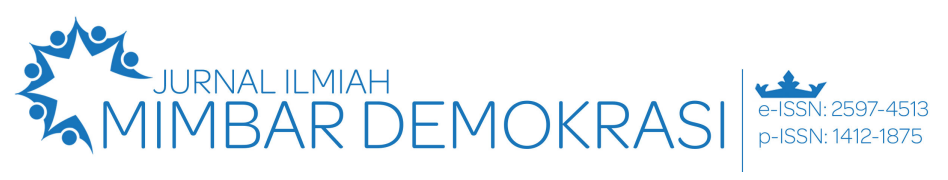

Vol. 21 No. 1 October 2021 | Hal. 8 - 18

menggunakan hak pilihnya. Hasil temuan penelitian, membuktikan bahwa praktik politik uang pada pilkada tahun 2020 khususnya di wilayah Benda Baru Kecamatan Pamulang masih terjadi menjelang hari pencoblosan. Bahkan mereka mengungkapkan bahwa pemberian uang oleh oknum tim sukses dengan nominal yang variatif.

Beberapa pernyataan yang diperoleh dari hasil interview dengan sejumlah informan terungkap bahwa politik jual beli suara memang ada, akan tetapi untuk membuktikannya perlu dikuatkan dengan data yang akurat. Karena warga terkesan tutup mulut. Bahkan disaat peneliti menanyakan terkait dengan politik uang, terdapat beberapa warga di wilayah Kelurahan Benda Baru Pamulang tidak bersedia menjawab. Dengan demikian, maka hal tersebut justru memperkuat asumsi bahwa politik uang menjelang pemilihan umum kepala daerah memang benar ada tetapi sulit untuk dibuktikan. Praktik politik uang (money politics) tidak dapat dihindari di ajang pemilihan kepala daerah (pilkada). Fenomena ini sering terjadi, baik pemilihan secara langsung atau tidak langsung.

Yang oleh Mahfud MD, dikatakan bahwa politik uang hanya berupa bentuk dari pemilihan kepala daerah oleh DPRD maupun pemilihan kepala daerah secara langsung dipilih rakyat. Lanjut, Mahfud, bahwa jika pemilihan secara langsung, maka politik uang yang diberikan berupa eceran, kalau lewat DPRD itu borongan, kita bayar ke partai, kalau ke rakyat, bayar ke rakyat pakai amplop satu persatu. Jadi, tinggal kita mau eceran apa borongan, samasama tidak bisa hindari pada waktu itu. Mahfud mengakui, praktik politik uang ini bukan hal yang mudah diatasi (CNN, 2020).

Senada dengan itu, ungkap oleh Siti Zuhro, bahwa praktik ini biasanya dilakukan karena para calon memanfaatkan kondisi ekonomi rakyat. Lebih lanjut dikatakan Zuhro, praktik-praktik seperti ini dihindari oleh para peserta pilkada demi kualitas demokrasi yang lebih baik. Memang ada yang tidak mampu, masih menghadapi kemiskinan dan sebagainya, tapi janganlah kesengsaraan masyarakat itu dieksploitasi dengan uang receh (Zuhro, 2019).

Oleh karena itu, dengan adanya politik uang (money politics) itu, diperlukan keseriusan penyelenggara pemilu dalam penegakkan hukum dan pengawasan yang ketat serta sanksi yang berat bagi yang menerima maupun calon kepala daerah yang melakukan praktik-praktik curang dalam pemilihan umum seperti politik uang (money politics).

Pilkada serantak yang dilaksanakan di tengah pandemi Covid-19 yang belum mereda. Sehingga sejumlah masyarakat masih diliputi rasa khawatir, bahwa pelaksanaan pilkada melalui tahapan kampanye calon hingga pada pemungutan suara di Tempat Pemungutan Suara (TPS) akan menimbulkan kluster baru kasus Covid-19. Meskipun demikian, pelaksanaan pilkada tetap berlangsung sesuai dengan protokol kesehatan.

Menyelenggarakan pemilihan umum (Pilkada) di tengah pandemi Covid-19 memang merupakan sebuah tantangan tersendiri. Satu hal yang terpenting adalah kesehatan dan keselamatan masyarakat tetap menjadi yang utama. Maka dari itu, pelaksanaan protokol kesehatan harus dilakukan secara ketat oleh penyelenggara pemilu untuk menjamin keselamatan masyarakat. Namun demikian, situasi di lapangan nampaknya masih terdapat banyak pelanggaran protokol kesehatan, baik dilakukan para pasangan calon, pendukungnya maupun warga masyarakat yang mempunyai hak pilih.

Munculnya pemilih yang rasional terkait dengan beberapa kondisi, yaitu Pertama, tingkat pendidikan yang memadai karena berhubungan dengan kemampuan pemilih melakukan pertimbangan berdasarkan akal sehat dan logika politik yang lazim. Kedua, faktor kondisi ekonomi yang mapan atau memadai, yaitu kesungguhan pemilih untuk berkonsentrasi pada pertimbangan politiknya tanpa dipengaruhi oleh hal-hal lain. Ketiga, kondisi yang kondusif terkait dengan keadaan lingkungan sekitar yang mendukung pemilih untuk memberikan suara politiknya saat pemilu (Asrinaldi, 2014).

Selain itu, faktor uang juga menjadi penentu warga masyarakat dalam pemilihan kepala daerah Kota Tangerang Selatan. Di beberapa lokasi wilayah Benda Baru Kecamatan Pamulang, dari hasil wawancara terungkap bahwa warga dalam menyalurkan hak suaranya atas dasar politik uang. Politik uang ini juga memberikan andil yang cukup besar dalam mempengaruhi pilihan politik warga di wilayah Benda Baru Kecamatan Pamulang. Politik uang (money politics) terjadi di beberapa tempat di wilayah Benda Baru yang dilakukan beberapa oknum-oknum tertentu dengan cara membagibagikan amplop berisikan sejumlah uang kepada sejumlah warga masyarakat dengan 
pesan untuk memilih kandidat tertentu. Praktik politik uang yang seringkali terjadi dalam pemilu/pilkada di setiap daerah tidak dapat dihindari. Warga seolah-oleh menganggap hal ini adalah sesuatu yang sudah biasa terjadi. Fenomena politik uang yang sering terjadi pada setiap hajatan pilkada tentunya tidak terlepas dari perilaku oknum elit politik itu sendiri.

Berdasarkan hasil riset yang dilakukan The Latin Amarican Public Opinion Project (LAPOP) American Barometer, Afrobaromter, Money Politics Project di Asia Tenggara menunujukkan bahwa Indonesia berada pada peringkat 3 (tiga) dunia yang paling banyak melakukan praktik jual beli suara atau politik uang. Indonesia hanya kalah bersaing dibanding Uganda dan Benin (Pahlevi dan Amrurobbi, 2020).

Perilaku pemilih yang berorientasi pada uang juga disebabkan para oknum-oknum politisi tidak mampu memberikan pendidikan politik yang baik kepada warga masyarakat. Selain itu, juga perilaku koruptif oknum politisi. Sebagaimana diungkap Fitriyah dalam tulisannya yang berjudul "Fenomena Politik Uang dalam Pilkada" dikatakan bahwa suburnya politik uang juga tidak lepas dari cara pandang masyarakat pemilih yang permisif terhadap politik uang itu. Pada proses demokrasi di Indonesia termasuk demokrasi pada akar rumput, praktik politik uang tumbuh subur, karena dianggap suatu kewajaran, masyarakat tidak peka terhadap bahayanya. Mereka membiarkannya karena tidak merasa bahwa money politics secara normatif adalah perilaku yang harus dijauhi (Fitriyah, 2013).

Supriyanto (2005) menjelasakan bahwa berdasarkan aktor dan wilayah operasinya, politik uang bisa dibedakan menjadi 4 (empat) lingkaran, yaitu; Pertama, transaksi antara elit ekonomi (pemilik uang) dengan pasangan calon yang akan menjadi pengambil kebijakan/keputusan politik. Kedua, transaksi antara pasangan calon dengan partai politik yang mempunyai hak dalam mencalonkan. Ketiga, transaksi antara pasangan calon dan tim kampanye dengan petugas-petugas yang mempunyai kewenangan dalam menghitung perolehan suara. Dan yang keempat, transaksi antara calon dengan tim kampanye dengan massa pemilih (pembelian suara). Lebih lanjut dikatakan Supriyanto, bahwa di lingkaran keempat inilah pembelian suara langsung kepada pemilih (vote buying) terjadi. Terdapat sejumlah jenis yang masuk kategori jual beli suara tersebut, di antaranya adalah pemberian uang transpor kampanye, janji membagi uang/barang, pembagian sembako atau semen untuk membangun tempat ibadah, serangan fajar dan lain-lain (Supriyanto, 2005; Wahyu Yonan, 2018).

Praktik jual beli suara atau politik uang yang sering terjadi pada momen pemilu/pilkada ini sulit tersentuh oleh aparat penegak hukum. Di sisi lain adalah sulitnya pembuktian akibat tidak adanya batasan yang jelas mengenai politik uang, serta sebagian masyarakat menganggap hal ini merupakan sesuatu yang biasa saja. Dan ironisnya lagi, masyarakat semakin permisif dengan praktik politik uang dan jual beli suara di pemilu/pilkada. Dengan demikian, maka hal ini dapat dikatakan bahwa tingkat pendidikan dan kondisi ekonomi masyarakat yang masih rendah turut menjadi penyebab lahirnya pandangan politik yang sempit bahkan terkesan subjektif. Kondisi ini juga diperburuk dengan adanya tindakan beberapa oknum politisi yang menghalalkan segala cara untuk mencapai tujuan, sehingga menyebabkan pilihan politik menjadi tidak rasional.

Menurut Manzetti dan Wilson (2007), yang dikutip Pahlevi dan Amrurobbi (2020) mengungkapkan bahwa perilaku masyarakat yang cenderung lemah dalam mendapatkan informasi politik menjadi sasaran utama praktik politik uang.

Seharusnya para kontestan (pasangan calon) yang bertarung pada setiap pesta demokrasi (pilkada) dalam merekrut simpatisan (tim sukses) yaitu orang-orang yang memiliki kredibilitas dan mempunyai integritas yang tinggi dalam menjunjung tinggi arti dan tujuan demokrasi yang sesungguhnya, sehingga citacita demokrasi dapat tercapai sesuai dengan harapan rakyat. Para elite politik harus mampu meletakan nilai-nilai demokrasi yang sesuai dengan kepribadian masyarakat Indonesia yang menjunjung tingggi norma-norma dalam kehidupannya. Oleh karena itu, dalam setiap momentum pemilu/pilkada harus dijadikan pesta demokrasi yang dapat memberikan warna dan dinamika sosial yang lebih demokrastis dan beradab.

Masyarakat harus diberikan kebebasan dalam menentukan pilihannya, karena peran aktif masyarakat sangat menentukan dalam melahirkan sosok pemimpin yang berkualitas, pemimpin yang mampu menjembatani dan memberikan solusi terhadap persoalanpersoalan yang dihadapi masyarakat, pemimpin 


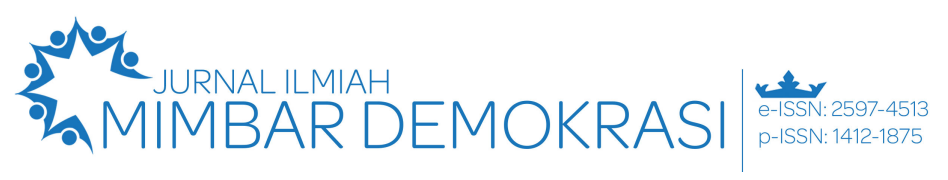

Vol. 21 No. 1 October 2021 | Hal. 8 - 18

yang dapat memwujudkan pemerintahan yang adil sesuai apa yang menjadi cita-cita masyarakat. Di lain pihak masyarakat juga harus lebih peka dan menjadi pemilih yang cerdas yang mampu membidik serta membedakan mana kandidat yang betul-betul bekerja untuk kepentingan rakyat dan mana yang hanya mengumbar janji-janjinya. Para calon pasangan harus memberikan sosialisasi politik (pendidikan politik) dengan menyajikan program-program yang dapat membawa dampak positif untuk masyarakat serta mampu meyakinkan pemilih (masyarakat) melalui upaya dan strategi kampanye yang lebih mendidik.

Sebagaimana dikatakan Kartono (1996), yang dikutip Pahlevi dan Amrurobbi (2020), mengungkapkan bahwa sosialisasi politik berbeda dengan pendidikan politik, pendidikan politik mengubah proses sosialisasi politik, sehingga masyarakat benar-benar mampu memahami nilai etis dalam perpolitikan dan mampu mempraktikannya.

Upaya dan strategi yang dapat dilakukan pasangan calon lewat kampanye dengan menggunakan berbagai media guna menarik simpati pemilih. Upaya dan strategi yang dapat dilakukan bisa saja dalam bentuk apapun, namun tetap berpegang pada syarat dan ketentuan yang telah ditetapkan dalam aturan pemilihan umum/pilkada. Sehingga perilaku pemilih dalam menyalurkan hak suaranya pada pemilu/pilkada tidak atas dasar politik uang (money politics), tendensi maupun ekspektasi, tetapi pilihan politiknya didasarkan pada nalar rasional dengan berpijak pada programprogram kerja dan visi misi yang ditawarkan oleh para calon pasangan.

Sebagaimana argumentasi Smith (1985) dan Arghiros (2001) yang dikutip Zuhro (2019), menyatakan bahwa nilai-nilai demokrasi telah mendasari perilaku, baik elite maupun masyarakat, untuk itu sebagian besar pemilih terlebih dulu perlu memiliki kesadaran dan kematangan politik yang cukup memadai. Dengan cara itu, masyarakat diasumsikan memiliki kapasitas untuk melakukan pilihan dan mengambil keputusan atas pilihannya berdasarkan rasionalitas politik (Zuhro, 2019).

Berdasarkan beberapa pendapat tersebut, maka dalam konteks politik diperlukan edukasi politik kepada warga masyarakat tentang konsekuensi menerima uang dari kegiatan politik yang dilakukan oleh oknum atau calon peserta pemilihan umum kepala daerah (pilkada). Dengan demikian, masyarakat akan memahami resiko yang mereka dapatkan dari politik uang tersebut, sehingga praktikpraktik politik curang seperti ini dapat dihindari, sehingga pada gilirannya akan melahirkan pesta demokrasi yang bermartabat dan berkualitas.

\section{Simpulan}

Berdasarkan hasil penelitian dan pembahasan yang telah dipaparkan di atas, maka dapat disimpulkan, bahwa; 1) Partisipasi pemilih pada ajang pemilihan kepala daerah tahun $2020 \mathrm{di}$ wilayah Benda Baru Pamulang sebanyak 18.982 jiwa atau mencapai 61 persen dan yang tidak menggunakan hak pilih sebanyak 12.132 atau mencapai 39 persen, dari total jumlah jiwa pilih sebanyak 31.114 jiwa pilih. Sementara perilaku pemilih dalam menentukan hak politiknya masih didominasi oleh sosok figur dan politik uang (money politics). 2) Kekhawatiran warga akan keselamatan jiwa akibat penularan wabah Covid19 yang menjadi faktor utama menurunnya partisipasi masyarakat dalam menggunakan hak pilih pada pemilihan umum kepala daerah di wilayah Benda Baru Pamulang Kota Tangerang Selatan.

\section{Referensi}

Asrinaldi, A. (2014). Pemilib Rasional dan Pemimpin Bekualitas, Media Indonesia.

Budiardjo, Miriam. (2000). Dasar-Dasar Ilmu Politik. Jakarta: PT. Gramedia

Cnnindonesia.com. (2020, 05 September). Survei LSI: 46 Persen Warga Enggan ke TPS Saat Pandemi Covid. Diakses pada 11 Januari 2021, dari https://www.cnnindonesia.com/nasional/20 200905170358-32-543169/survei-1si-46persen-warga-enggan-ke-tps-saat-pandemicovid.

Cnnindonesia.com. (2020, 09 Desember). Satgas Klaim Kepatuhan Pemilih Pakai Masker 96,59 Persen. Diakses pada 12 Desember 2020, dari https://www.cnnindonesia.com/nasional/20 201209183543-32-580164/satgas-klaimkepatuhan-pemilih-pakai-masker-9659persen.

Damsar. (2015). Pengantar Sosiolosi Politik. Edisi ke-2. Jakarta: Kencana Prenanda Media Group.

Didik Supriyanto. Terbatas, T. D. P. (2005). Politik Uang Dalam Pilkada. Hotel AcaciaJakarta, 30.

Fitriani, L. U., Karyadi, L. W., \& Chaniago, D. S. (2019). Fenomena Politik Uang (Money Politic) Pada Pemilihan Calon Anggota 
Legislatif di Desa Sandik Kecamatan Batu Layar Kabupaten Lombok Barat. RESIPROKAL: Jurnal Riset Sosiologi Progresif Aktual, 1(1), 53-61.

Fitriyah. (2013). Fenomena Politik Uang Dalam Pilkada. Politika: Jurnal Ilmu Politik, Vol. 3, Nomor 1, pp. 5-14, May. 2013.

Keputusan Presiden (Keppres) Nomor 12 Tahun 2020.

Kota-tangerangselatan.kpu.go.id. (2020). Daftar Pemilih Tetap. Diakses pada 10 Desember 2020, dari https://kota tangerangselatan.kpu.go.id/daftar-pemilihtetap/.

Metro.tempo.co. (2020, 16 Oktober). KPU Tangerang Selatan Tetapkan 976.019 Pemilih di Pilkada 2020. Diakses pada 12 Desember 2020, dari https://metro.tempo.co/read/1396669/kputangerang-selatan-tetapkan-976019-pemilihdi-pilkada-2020.

Moleong, Lexy.J. (2007). Metodologi Penelitian Kualitatif. Bandung: PT Remaja Rosdakarya

Mopeng, Esther. D. (2016). Jurnal: Perilaku Pemilih Pada Pemiliban Kepala Daerah Minahasa Utara. Ilmu pemerintahan FISIP Unsrat.

Nursal, Adman. (2004). Political Marketing: Strategi Menenangkan Pemilu, Sebuab Pendekatan Baru Kampanye Pemilihan DPD, DPRD. Jakarta: PT. Gramedia Pustaka Utama.

Pahlevi, M. E. T., \& Amrurobbi, A. A. (2020). Pendidikan Politik dalam Pencegahan Politik Uang Melalui Gerakan Masyarakat Desa. Integritas: Jurnal Antikorupsi, 6(1), 141-152.

Peraturan KPU Nomor 13 Tahun 2020 tentang Perubahan Kedua atas PKPU Nomor 6 Tahun 2020 tentang Pelaksanaan Pilkada Serentak.

Pilkada2015.kpu.go.id. (2015). Hasil Hitung TPS (Form C1) Kelurahan Benda Baru. Diakses pada 12 Januari 2021, dari https://pilkada2015.kpu.go.id/tangselkota/p amulang/benda baru.

Rejeki, S. (2016). Strategi Bertahan Hidup Pada Musim Paceklik (Studi Deskriptif Kehidupan Petani Miskin Di Desa Kaligede Kecamatan Senori Kabupaten Tuban) (Doctoral dissertation, UIN Sunan Ampel Surabaya).

Sugiyono. (2016). Metode Penelitian Kuantitatif, Kualitatif dan R\&D. Bandung: Alfabeta.

Undang-Undang Republik Indonesia Nomor 7 Tahun 2017 tentang Pemilihan Umum.

Wahyu, Yohan. (2018). Pembiayaan Pemilu di Indonesia: Politik Uang dalam Bingkai Opini
Publik. Jakarta: Badan Pengawas Pemilihan Umum Republik Indonesia.

Yunita, P. Ratih dan Stanislaus, Sugiyarta. (2014). Orientasi Politik Pemilih Pada Pemilu Legislatif Tabun 2014. Journal of Social and Industrial Psychology.

Zuhro, Siti. R (2019). Demokrasi dan Pemilu Presiden 2019. LIPI: Jurnal Penelitian Politik. Vol. 16. No.1 Juni 2019. 